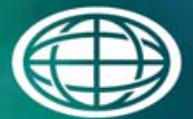

Savannah River

National Laboratory "m

OPERATED BY SAVANNAH RIVER NUCLEAR SOLUTIONS

\title{
Assessment of Performing an MST Strike in Tank 21H
}

Michael R. Poirier

September 2014

SRNL-STI-2014-00194, Rev. 0 


\section{DISCLAIMER}

This work was prepared under an agreement with and funded by the U.S. Government. Neither the U.S. Government or its employees, nor any of its contractors, subcontractors or their employees, makes any express or implied:

1. warranty or assumes any legal liability for the accuracy, completeness, or for the use or results of such use of any information, product, or process disclosed; or

2. representation that such use or results of such use would not infringe privately owned rights; or

3. endorsement or recommendation of any specifically identified commercial product, process, or service.

Any views and opinions of authors expressed in this work do not necessarily state or reflect those of the United States Government, or its contractors, or subcontractors.

\section{Printed in the United States of America \\ Prepared for U.S. Department of Energy}


Keywords: Mixin

Retention: Permanent

\section{Assessment of Performing an MST Strike in Tank 21}

M. R. Poirier

September 2014

Prepared for the U.S. Department of Energy under contract number DE-AC09-08SR22470. 


\section{REVIEWS AND APPROVALS}

\section{AUTHORS:}

\section{TECHNICAL REVIEW:}

\section{QUALITY ASSURANCE REVIEW:}

W. A. Drown, SRNL QA

Date

\section{APPROVAL:}

F. M. Pennebaker, Manager

Date

Advanced Characterization and Processing

S. L. Marra, Manager

Date

Environmental \& Chemical Process Technology Research Programs

A. V. Staub

Date

Tank Farm Engineering 


\section{EXECUTIVE SUMMARY}

Previous Savannah River National Laboratory (SRNL) tank mixing studies performed for the Small Column Ion Exchange (SCIX) project have shown that 3 Submersible Mixer Pumps (SMPs) installed in Tank 41 are sufficient to support actinide removal by MST sorption as well as subsequent resuspension and removal of settled solids. Savannah River Remediation (SRR) is pursuing MST addition into Tank 21 as part of the Large Tank Strike (LTS) project. The preliminary scope for LTS involves the use of three standard slurry pumps (installed in N, SE, and SW risers) in a Type IV tank. Due to the differences in tank size, internal interferences, and pump design, a separate mixing evaluation is required to determine if the proposed configuration will allow for MST suspension and strontium and actinide sorption.

The author performed the analysis by reviewing drawings for Tank 21 [W231023] and determining the required cleaning radius or zone of influence for the pumps. This requirement was compared with previous pilot-scale MST suspension data collected for SCIX that determined the cleaning radius, or zone of influence, as a function of pump operating parameters. The author also reviewed a previous Tank 50 mixing analysis that examined the ability of standard slurry pumps to suspend sludge particles.

Based on a review of the pilot-scale SCIX mixing tests and Tank 50 pump operating experience, three standard slurry pumps should be able to suspend sludge and MST to effectively sorb strontium and actinides onto the MST. Using the SCIX data requires an assumption about the impact of cooling coils on slurry pump mixing. The basis for this assumption is described in this report. Using the Tank 50 operating experience shows three standard slurry pumps should be able to suspend solids if the shear strength of the settled solids is less than $160 \mathrm{~Pa}$. Because Tank 21 does not contain cooling coils, the shear strength could be larger.

The author makes the following recommendations:

- Operate the slurry pumps while adding the MST to Tank 21 and performing the MST strike. The slurry pumps should be started and rotating prior to the addition of MST to Tank 21. In addition, the MST should be added as close as possible to one of the mixer pumps. By operating the pumps and adding the MST close to one of the pumps, the MST will be better dispersed throughout the tank, making the sorption process more effective. The sorption time clock should start when the MST addition is complete.

- Remove the sludge from Tank 21 before performing the MST strike. Removing the sludge from Tank 21 prior to the MST strikes reduces uncertainty in the process. Removing the sludge is less important if the added MST is suspended since the strontium and actinide sorption occurs on the freshly added MST. Not removing the sludge prior to the MST strike could make heel removal more difficult at the end of the Large Tank Strike program.

- If the sludge is not removed before performing the MST strike, measure the shear strength of the sludge in Tank 21 prior to performing the first MST strike, and mix the sludge every three months. The three months is based on the pilot-scale SCIX testing and the SCIX Rheology testing. The pilot-scale SCIX testing allowed the solids to settle for four weeks prior to resuspension. The rheology testing allowed samples to settle for up to 13 weeks. Additionally, analysis of the solid particles should be considered.

- If routine solids mixing in Tank 21 is not desirable for process reasons, the author recommends that additional rheology testing be conducted with sludge and MST to determine the impact of longer settling times on the slurry rheology. The solids in Tank 21 following the large tank strike will be composed primarily of sludge particles. The SRS Tank Farms have successfully transferred sludge from waste tanks that sat for much longer than three months. 


\section{TABLE OF CONTENTS}

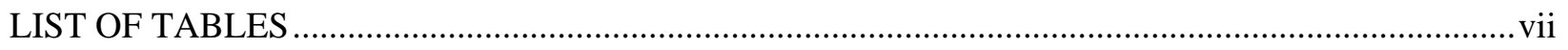

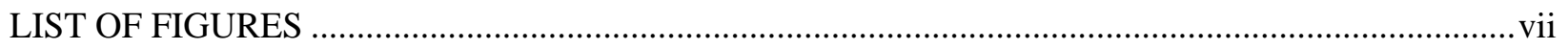

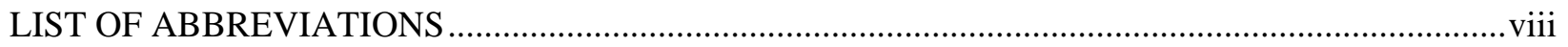

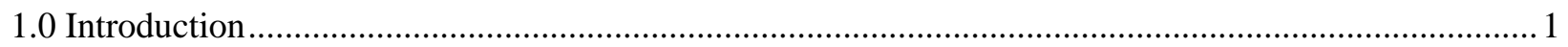

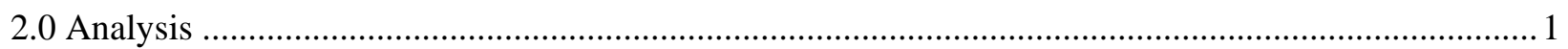

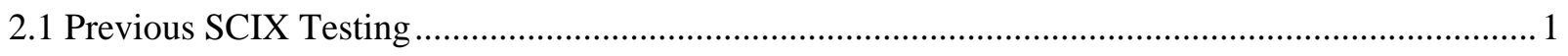

2.2 Previous Tank 50 Operating Experience ….............................................................................. 3

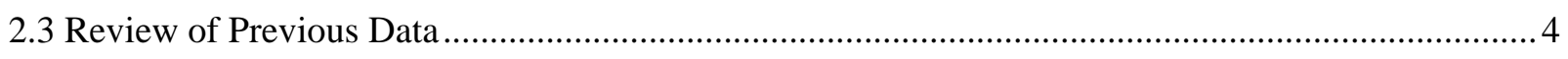

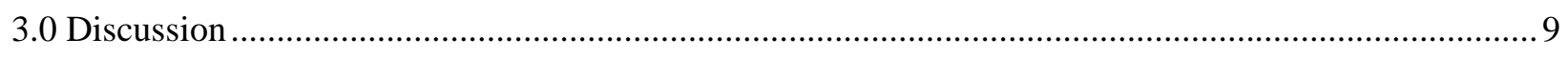

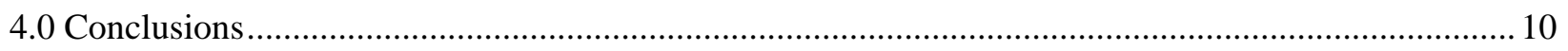

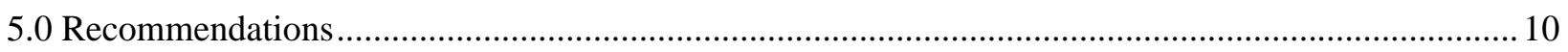

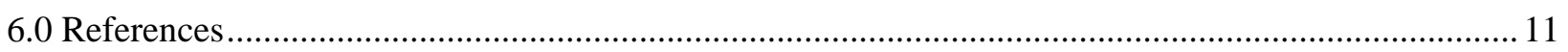




\section{LIST OF TABLES}

Table 1. QA Checklist for Data Collected for this Task ............................................................................ 5

\section{LIST OF FIGURES}

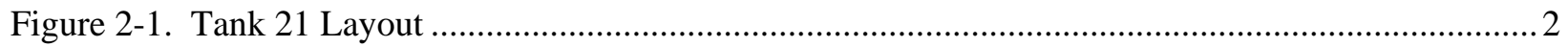

Figure 2-2. Cleaning Radius as a Function of $\mathrm{U}_{0} \mathrm{D}$ for MST Suspension.............................................. 3 


\section{LIST OF ABBREVIATIONS}

$\begin{array}{ll}\text { C } & \text { Constant } \\ \text { D } & \text { Pump nozzle diameter } \\ \mathrm{D}_{\text {tank }} & \text { Tank diameter } \\ \text { ECR } & \text { Effective cleaning radius } \\ \text { LTS } & \text { Large Tank Strike } \\ \text { MST } & \text { Monosodium titanate } \\ \text { N } & \text { North } \\ \text { NE } & \text { Northeast } \\ \text { NW } & \text { Northwest } \\ \text { SCIX } & \text { Small Column Ion Exchange } \\ \text { SE } & \text { Southeast } \\ \text { SMP } & \text { Submersible Mixer Pump } \\ \text { SRNL } & \text { Savannah River National Laboratory } \\ \text { SRR } & \text { Savannah River Remediation } \\ \text { SW } & \text { Southwest } \\ \text { TTP } & \text { Telescoping transfer pump } \\ \mathrm{U}_{o} & \text { Pump discharge velocity } \\ \rho & \text { Density } \\ \tau_{y} & \text { Yield stress } \\ \tau_{\mathrm{s}} & \text { Shear strength }\end{array}$




\subsection{Introduction}

Previous Savannah River National Laboratory (SRNL) tank mixing studies performed for the Small Column Ion Exchange (SCIX) project have shown that 3 Submersible Mixer Pumps (SMPs) installed in Tank 41 are sufficient to support actinide removal by MST sorption as well as subsequent resuspension and removal of settled solids. ${ }^{1,2,3}$ Savannah River Remediation (SRR) is pursuing MST addition into Tank 21 as part of the Large Tank Strike (LTS) project. The preliminary scope for LTS involves the use of three standard slurry pumps (installed in N, SE, and SW risers) in a Type IV tank. Due to the differences in tank size, internal interferences, and pump design, a separate mixing evaluation is required to determine if the proposed configuration will allow for MST suspension and strontium and actinide sorption. ${ }^{4}$

SRR requested SRNL to perform a technical review of previous tank mixing studies ${ }^{1,2,3}$ to determine the effectiveness of the proposed strategy for a Large Tank Strike in Tank 21. If a three standard slurry pump configuration is shown to be inadequate or marginal, the analysis will consider strategies of four standard slurry pumps (NE, NW, SE, and SW risers) or an SMP located in the North Riser with standard slurry pumps in the SE and SW risers. The evaluation provides an estimate of the level of confidence or conservatism in the analysis, as well as risk. This report documents the conclusions of the analysis.

\subsection{Analysis}

The author performed the analysis by reviewing drawings for Tank 21 [W231023] and determining the required cleaning radius or zone of influence for the pumps. This requirement was compared with previous pilot-scale MST suspension data collected for SCIX that determined the cleaning radius, or zone of influence, as a function of pump operating parameters. ${ }^{1,2,3}$ The author also reviewed a previous Tank 50 mixing analysis that examined the ability of standard slurry pumps to suspend sludge particles. ${ }^{5}$

\subsection{Previous SCIX Testing}

Figure 2-1 shows a layout of the tank, as well as the proposed locations of the standard slurry pumps. According to the drawing [W231023], the tank diameter is 85.06 feet (42.53 foot radius), the pumps are located on a 37 foot radius, and the pumps are located $120^{\circ}$ apart. The farthest distance that the pumps will be required to reach and suspend particles is at the wall, midway between two pumps. If the pump locations are defined as radius 37 feet and angular positions, $60^{\circ}, 180^{\circ}$, and $-60^{\circ}$, the farthest distance from a pump is located at $\left(42.53 \mathrm{ft}, 0^{\circ}\right),\left(42.53 \mathrm{ft}, 120^{\circ}\right)$, and $\left(42.53 \mathrm{ft},-120^{\circ}\right)$. The distance between the pump located at $60^{\circ}$ and the wall located at $0^{\circ}$ is described by equation [1].

$$
d=\sqrt{(37 \cos (60)-42.53 \cos (0))^{2}+(37 \sin (60)-42.53 \sin (0))^{2}}=40.0 \mathrm{ft} \text { [1] }
$$

Points $\left(42.53 \mathrm{ft}, 120^{\circ}\right)$ and $\left(42.53 \mathrm{ft},-120^{\circ}\right)$ would be $40.0 \mathrm{ft}$ from the closest pump, also. The pilot-scale MST suspension tests conducted for SCIX were performed in a 1/10.6 linear scale tank. At this scale, the equivalent required cleaning radius would be $40.0 \mathrm{ft} / 10.6=3.77 \mathrm{ft}=$ 45.3 in.

Figure 2-2 shows the measured cleaning radius from the pilot-scale MST suspension tests. From the plot, the $\mathrm{U}_{0} \mathrm{D}$ required to produce a 45.3 inch cleaning radius is $1.4 \mathrm{ft}^{2} / \mathrm{s}$. The scaling analysis performed for the SCIX testing showed that the nozzle velocity for full-scale operation needed to 
be $30 \%$ larger that the nozzle velocity in the pilot-scale testing for equivalent MST suspension. ${ }^{3}$ Equation [2] shows the calculation of the required $U_{0} D$ for suspending MST in Tank 21.

$$
\mathrm{U}_{0} \mathrm{D}_{\text {full-scale }}=\mathrm{U}_{0} \mathrm{D}_{\text {pilot-scale }}\left(\mathrm{D}_{\text {full-scale }} / \mathrm{D}_{\text {pilot-scale }}\right)(1.3)=\left(1.4 \mathrm{ft}^{2} / \mathrm{s}\right)(10.6)(1.3)=19.3 \mathrm{ft}^{2} / \mathrm{s} \quad[2]
$$

The required $\mathrm{U}_{0} \mathrm{D}$ needed to suspend the MST in Tank 21 for strontium and actinide sorption $\left(19.3 \mathrm{ft}^{2} / \mathrm{s}\right)$ is significantly larger than the $\mathrm{U}_{0} \mathrm{D}$ of a standard slurry pump $\left(13.6 \mathrm{ft}^{2} / \mathrm{s}\right)$.

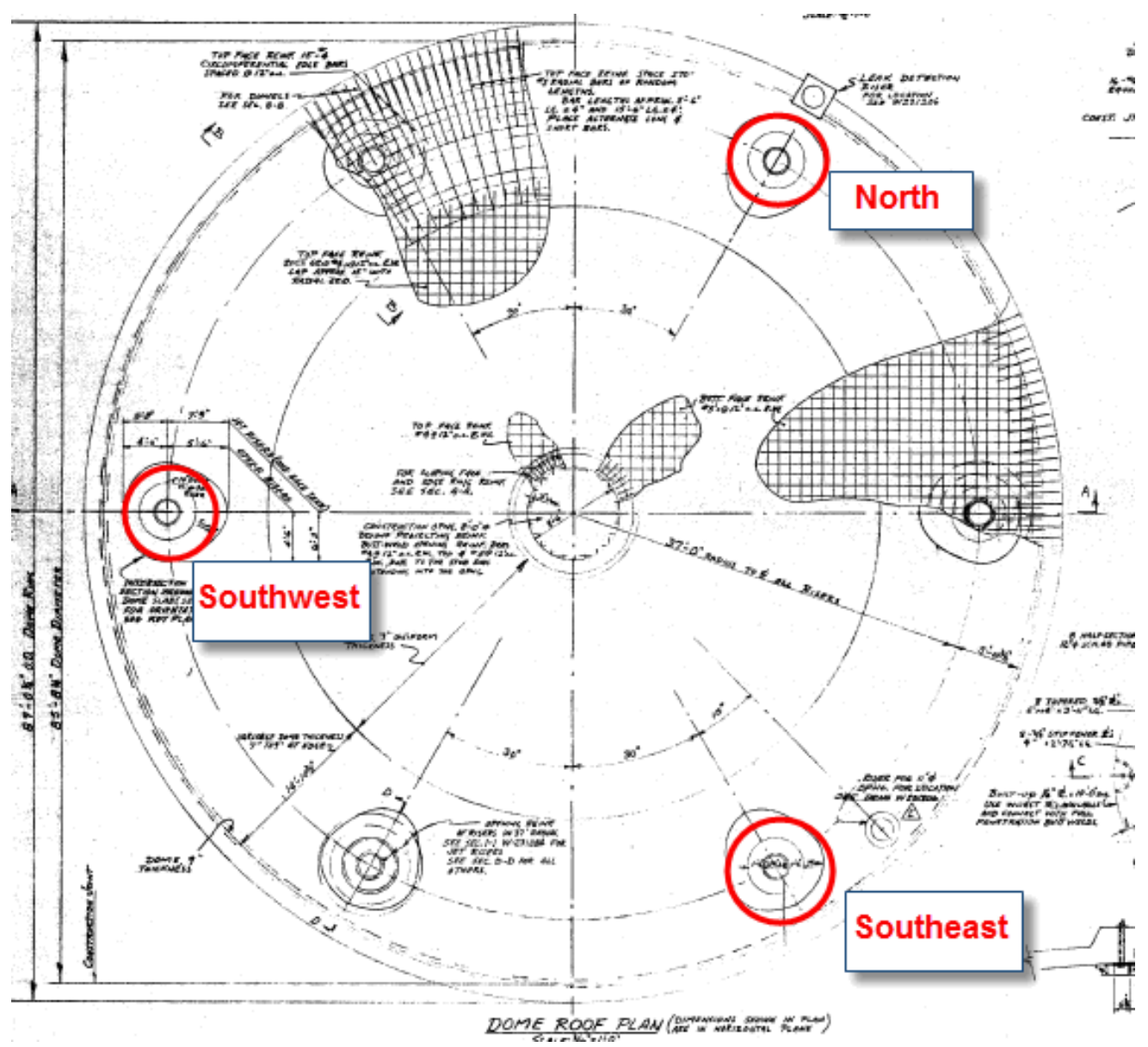

Figure 2-1. Tank 21 Layout

However, Tank 21 does not contain cooling coils, while the pilot-scale tank did contain cooling coils. The absence of cooling coils will lead to a more powerful jet farther away from the pumps. Models for effective cleaning radius of slurry pumps show that the cleaning radius is proportional to $\mathrm{U}_{\mathrm{j}} \mathrm{D}_{\mathrm{j}}$ (see equation [3]). ${ }^{6}$

$$
\operatorname{ECR}=C D_{j} V_{j}\left(\rho / \tau_{y}\right)^{1 / 2}
$$

In equation [3], $C$ is a constant, $D_{j}$ is the pump nozzle diameter, $V_{j}$ is the pump nozzle velocity, $\rho$ is the fluid density, and $\tau_{\mathrm{y}}$ is the slurry yield stress.

In addition, models for miscible liquid blend time show the blend time to be inversely proportional to $\mathrm{U}_{\mathrm{j}} \mathrm{D}_{\mathrm{j}}$ (see equation [4]). ${ }^{6}$ 


$$
\mathrm{t}=\mathrm{C} \frac{\mathrm{D}_{\operatorname{tank}} \mathrm{K}^{2}}{\mathrm{~V}_{\mathrm{j}} \mathrm{D}_{\mathrm{j}}}
$$

In equation [4], $D_{\text {tank }}$ is the tank diameter.

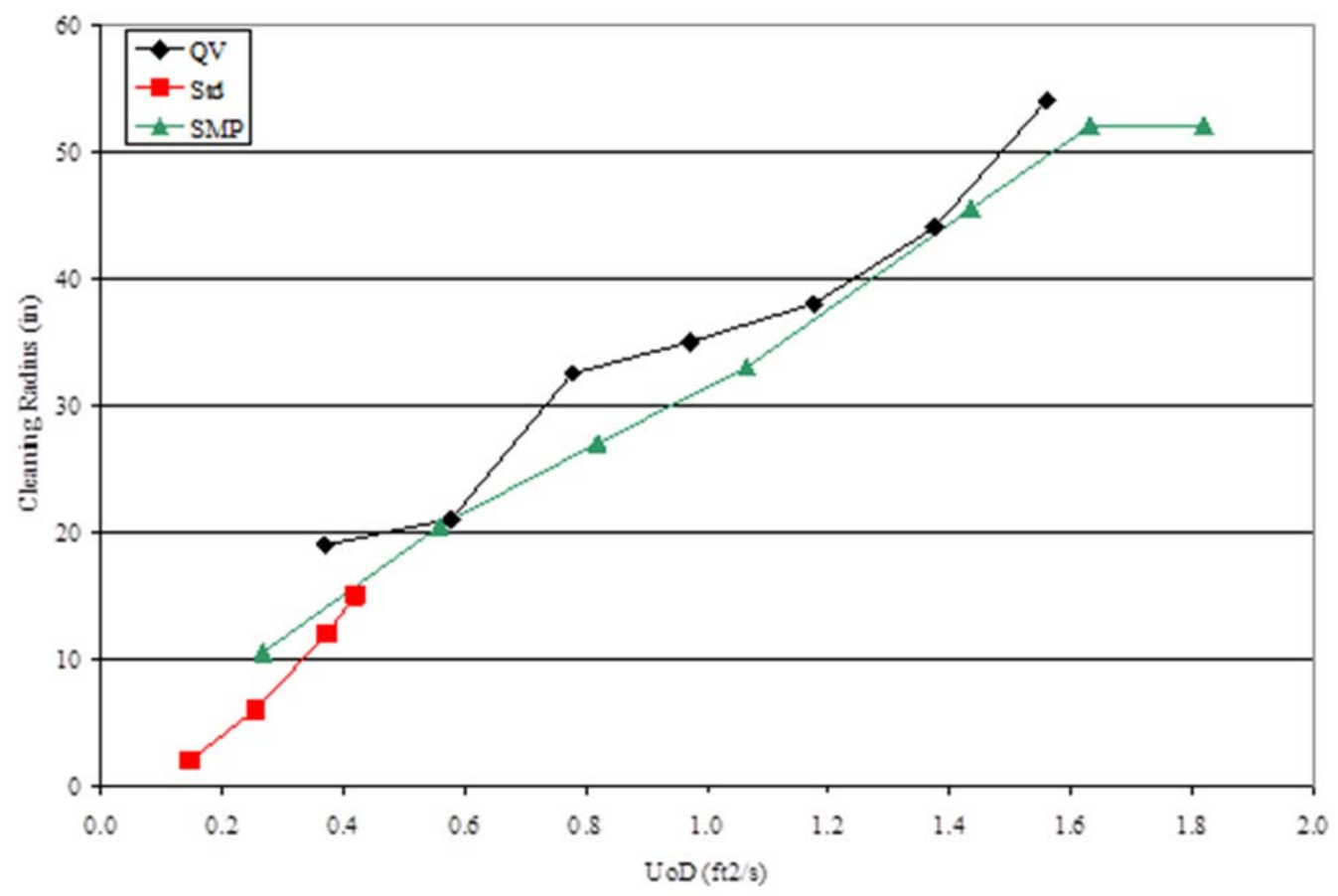

Figure 2-2. Cleaning Radius as a Function of $\mathbf{U}_{0} D$ for MST Suspension

Pilot-scale testing conducted by SRNL to measure the time to blend miscible liquids in a waste tank showed that the addition of cooling coils increased the miscible liquid blending time by a factor of 2. ${ }^{7}$ Since the tank diameter did not change, the results could be interpreted as decreasing the effective $\mathrm{U}_{0} \mathrm{D}$ by a factor of 2 . Likewise, removing the cooling coils could be interpreted as increasing the effective $U_{0} D$ by a factor of two, or decreasing the required $U_{0} D$ by a factor of 2 . Using this assumption, the required $\mathrm{U}_{0} \mathrm{D}$ to suspend the MST in Tank 21 is $9.7 \mathrm{ft}^{2} / \mathrm{s}$, which is $30 \%$ less than the maximum $\mathrm{U}_{0} \mathrm{D}$ of a standard slurry pump $(13.6 \mathrm{ft} 2 / \mathrm{s})$.

This analysis assumes that the impact of the cooling coils is the same for solids suspension as it is for miscible liquid blending, and that the removal of cooling coils decreases the required $U_{0} \mathrm{D}$ by a factor of 2 .

\subsection{Previous Tank 50 Operating Experience}

Another approach to assessing the ability of three standard slurry pumps to suspend MST in Tank 21 is to look at the operating experience of standard slurry pumps in Tank $50 .^{5}$ Engineering Calculation J-CLC-H-00793 determined the size and location of the mounds observed in Tank $50 \mathrm{H}$ in 2003. ${ }^{8}$ Standard slurry pumps were located in risers E1 and B2. One of the mounds was located under the TTP (riser B5). The distance from the pump in riser E1 to the mound was 30.7 feet. The distance from the pump in riser B2 to the mound was 33.5 feet. Based on this calculation, the cleaning radius of the standard slurry pump was 30.7 - 33.5 feet with the solids in Tank 50. 
SRNL measured the shear strength of a sample of the solids and found the shear strength to be 400 - 460 Pa for an undisturbed sample. ${ }^{9}$ Previous SRNL work found the cleaning radius of a slurry pump to be inversely proportional to the square root of the slurry yield stress. ${ }^{10,11}$ Previous PNNL work found the cleaning radius to vary with slurry shear strength according to equation [5]

$$
\operatorname{ECR} \alpha \mathrm{D}_{\mathrm{j}} \mathrm{U}_{\mathrm{j}} \tau_{\mathrm{s}}^{-0.46}
$$

where $\tau_{\mathrm{s}}$ is the sludge shear strength. ${ }^{12}$ Assuming the shear strength of the solid mounds in Tank 50 was $400 \mathrm{~Pa}$, the cleaning radius was 30 feet, and the target cleaning radius in Tank 21 is 45.3 feet, the shear strength of any solid particles or mounds must be less than $160 \mathrm{~Pa}$ if the standard slurry pumps are to be able to suspend the sludge throughout the vessel. Since Tank 50 contains cooling coils and Tank 21 does not, the shear strength of the sludge in Tank 21 could be larger.

Rheology data collected for the SCIX program with simulated sludge and MST (in a 660:1 ratio) that had settled for $1-13$ weeks at $30-45{ }^{\circ} \mathrm{C}$ had a measured shear strength less than $100 \mathrm{~Pa} .{ }^{13}$

\subsection{Review of Previous Data}

Because this task is classified as safety significant and the previous work was classified as production support, the data must be qualified as safety significant. To qualify the data, design verification and data qualification were conducted on the previous data according to the requirements of E7, procedures 3.60 and 3.70 .

The Data Qualification was conducted as follows. The procedural controls and requirements applicable to the quality of the data were identified in the TTQAP for this task (SRNL-RP-201400433). ${ }^{5}$ The non-qualified data used in this task are contained in references $1,2,6,7$, and 13. The TTQAPs for these tasks (SRNL-RP-2010-00081, SRNL-RP-2010-00686, SRNL-RP-201101114) were reviewed to determine the procedural controls and quality requirements of the testing performed to obtain the data. In performing the comparisons between the procedural controls and requirements for this task with the procedural controls and requirements for the data to be qualified in references $1,2,6,7$, and 13, differences were observed. These differences and their impact are discussed below.

Table 1 shows the Quality Assurance Checklist for the following TTQAPs: SRNL-RP-201400433, SRNL-RP-2010-00081, SRNL-RP-2010-00686, and SRNL-RP-2011-01114. Procedure 1Q, QAP 2-7 is not applicable in SRNL-RP-2011-01114, but is applicable in the other tasks. The reason for this difference is that SRNL-RP-2011-01114 is an Engineering Study and did not require analytical measurements. The present task (SRNL-RP-2014-00433) requires design control, but the others did not. The reason for implementing design control is for technical reviews of reports. The previous tasks conducted technical reviews of reports according to E7, 2.60 and E7, 3.60. Instructions, Procedures, and Drawings (1Q, QAP 5-1), Identification and Control of Items (1Q, QAP 8-1), Control of Nonconforming Items (1Q, QAP 15-1), and Corrective Action Program (1B, MRP 4.23) were not required for the work in SRNL-RP-201101114 , because that task was an engineering study rather than experimental work. The work in SRNL-RP-2011-01114 did not use M\&TE, so that procedure was not required. The Management Assessment Program (1Q, QAP 18-4) was not used in the task described by SRNL-RP-201000081, but that will not affect the quality of the collected data. The work described by SRNLRP-2010-00081 is not technical baseline, but the data was technically reviewed according to E7, 2.60 and E7, 3.60. 
Table 1. QA Checklist for Data Collected for this Task

\begin{tabular}{|c|c|c|c|c|c|}
\hline $\begin{array}{l}\text { QA Manual } \\
\text { Sections }\end{array}$ & Implementing Procedures & $\begin{array}{l}\text { SRNL- } \\
\text { RP- } \\
\text { 2014- } \\
00433\end{array}$ & $\begin{array}{l}\text { SRNL- } \\
\text { RP- } \\
\text { 2011- } \\
\text { 01114 }\end{array}$ & $\begin{array}{l}\text { SRNL- } \\
\text { RP- } \\
\text { 2010- } \\
00686\end{array}$ & $\begin{array}{l}\text { SRNL- } \\
\text { RP- } \\
\text { 2010- } \\
\text { 00081 }\end{array}$ \\
\hline \multirow[t]{3}{*}{ Organization } & \multirow{2}{*}{$\begin{array}{l}\text { 1Q, QAP 1-1, Organization } \\
\qquad \quad \text { L1, 1.02, SRNL } \\
\text { Organization }\end{array}$} & $\mathbf{Y}$ & $\mathbf{Y}$ & $\mathbf{Y}$ & $\mathbf{Y}$ \\
\hline & & $\mathbf{Y}$ & $\mathbf{Y}$ & $\mathbf{Y}$ & $\mathbf{Y}$ \\
\hline & 1Q, QAP 1-2, Stop Work & $\mathbf{Y}$ & AR & AR & AR \\
\hline \multirow{7}{*}{$\begin{array}{l}\text { Quality } \\
\text { Assurance } \\
\text { Program }\end{array}$} & \multirow{2}{*}{$\begin{array}{l}\text { 1Q, QAP 2-1, Quality Assurance } \\
\text { Program } \\
\bullet \text { L1, 8.02, SRNL QA } \\
\text { Program Implementation } \\
\text { and Clarification }\end{array}$} & $\mathbf{Y}$ & $\mathbf{Y}$ & $\mathbf{Y}$ & $\mathbf{Y}$ \\
\hline & & $\mathbf{Y}$ & $\mathbf{Y}$ & $\mathbf{Y}$ & $\mathbf{Y}$ \\
\hline & \multirow{2}{*}{$\begin{array}{l}\text { 1Q, QAP 2-2, Personnel Training } \\
\text { \& Qualification } \\
\qquad \quad \text { L1, 1.32, Read and } \\
\text { Sign/Briefing Program }\end{array}$} & $\mathbf{Y}$ & $\mathbf{Y}$ & $\mathbf{Y}$ & AR \\
\hline & & $\mathbf{Y}$ & $\mathbf{Y}$ & $\mathbf{Y}$ & $\mathbf{A R}$ \\
\hline & \multirow{2}{*}{$\begin{array}{l}\text { 1Q, QAP 2-3, Control of } \\
\text { Research and Development } \\
\text { Activities } \\
\text { • L1, 7.10 Identification of } \\
\text { Technical Work } \\
\text { Requirements }\end{array}$} & $\mathbf{Y}$ & $\mathbf{Y}$ & $\mathbf{Y}$ & $\mathbf{Y}$ \\
\hline & & $\mathbf{Y}$ & $\mathbf{Y}$ & $\mathbf{Y}$ & $\mathbf{Y}$ \\
\hline & $\begin{array}{l}\text { 1Q, QAP 2-7, QA Program } \\
\text { Requirements for Analytical } \\
\text { Measurement Systems }\end{array}$ & AR & $\mathbf{N}$ & $\mathbf{Y}$ & $\mathbf{Y}$ \\
\hline \multirow{3}{*}{$\begin{array}{l}\text { Design } \\
\text { Control }\end{array}$} & \multirow{3}{*}{$\begin{array}{l}\text { 1Q, QAP 3-1, Design Control } \\
\text { - E7, 2.60, Technical } \\
\text { Reviews } \\
\text { - E7, 3.60, Technical } \\
\text { Reports }\end{array}$} & $\mathbf{Y}$ & $\mathbf{N}$ & $\mathbf{N}$ & $\mathbf{N}$ \\
\hline & & $\mathbf{Y}$ & & & \\
\hline & & $\mathbf{Y}$ & & & \\
\hline \multirow{4}{*}{$\begin{array}{l}\text { Procurement } \\
\text { Document } \\
\text { Control }\end{array}$} & \multirow{4}{*}{$\begin{array}{ll}\text { 1Q, QAP 4-1, Procurement } \\
\text { Document Control } \\
\text { • } \\
\text { 7B, Procurement } \\
\text { Management Manual } \\
\text { - } & \text { 3E, Procurement } \\
& \text { Specification Procedure } \\
& \text { Manual } \\
\text { - } & \text { E7, 3.10, Determination } \\
& \text { of Quality Requirements } \\
& \text { for Procured Items }\end{array}$} & $\mathbf{N}$ & $\mathbf{N}$ & AR & $\mathbf{A R}$ \\
\hline & & $\mathbf{N}$ & $\mathbf{N}$ & AR & AR \\
\hline & & $\mathbf{N}$ & $\mathbf{N}$ & AR & AR \\
\hline & & $\mathbf{N}$ & $\mathbf{N}$ & AR & AR \\
\hline
\end{tabular}




\begin{tabular}{|c|c|c|c|c|c|}
\hline $\begin{array}{l}\text { QA Manual } \\
\text { Sections }\end{array}$ & Implementing Procedures & $\begin{array}{l}\text { SRNL- } \\
\text { RP- } \\
\text { 2014- } \\
00433\end{array}$ & $\begin{array}{l}\text { SRNL- } \\
\text { RP- } \\
\text { 2011- } \\
01114\end{array}$ & $\begin{array}{l}\text { SRNL- } \\
\text { RP- } \\
\text { 2010- } \\
00686\end{array}$ & $\begin{array}{l}\text { SRNL- } \\
\text { RP- } \\
\text { 2010- } \\
\text { 00081 }\end{array}$ \\
\hline \multirow{4}{*}{$\begin{array}{l}\text { Instructions, } \\
\text { Procedures } \\
\text { and } \\
\text { Drawings }\end{array}$} & \multirow{4}{*}{$\begin{array}{l}\text { 1Q, QAP 5-1, Instructions, } \\
\text { Procedures and Drawings } \\
\text { - L1, 1.01, Administration } \\
\text { of SRNL Procedures and } \\
\text { Work Instructions } \\
\text { - L1, 7.26 R\&D Work } \\
\text { Control Documents } \\
\text { - } \quad \text { E7, } 2.30 \text { Drawings }\end{array}$} & $\mathbf{Y}$ & $\mathbf{N}$ & $\mathbf{Y}$ & AR \\
\hline & & $\mathbf{Y}$ & $\mathbf{N}$ & $\mathbf{Y}$ & $\mathbf{Y}$ \\
\hline & & $\mathbf{Y}$ & $\mathbf{N}$ & $\mathbf{Y}$ & AR \\
\hline & & $\mathbf{N}$ & $\mathbf{N}$ & $\mathbf{N}$ & $\mathbf{N}$ \\
\hline \multirow{2}{*}{$\begin{array}{l}\text { Document } \\
\text { Control }\end{array}$} & \multirow{2}{*}{$\begin{array}{l}\text { 1Q, QAP 6-1, Document Control } \\
\text { - 1B, MRP 3.32, Document } \\
\text { Control }\end{array}$} & $\mathbf{Y}$ & $\mathbf{Y}$ & $\mathbf{Y}$ & $\mathbf{Y}$ \\
\hline & & $\mathbf{Y}$ & $\mathbf{Y}$ & $\mathbf{Y}$ & $\mathbf{Y}$ \\
\hline \multirow{5}{*}{$\begin{array}{l}\text { Control of } \\
\text { Purchased } \\
\text { Items and } \\
\text { Services }\end{array}$} & \multirow{3}{*}{$\begin{array}{l}\text { 1Q, QAP 7-2, Control of } \\
\text { Purchased Items and Services } \\
\text { • } \\
\text { 7B, Procurement } \\
\text { Management Manual } \\
\text { - } \\
\text { 3E, Procurement } \\
\text { Specification Procedure } \\
\text { Manual }\end{array}$} & $\mathbf{N}$ & $\mathbf{N}$ & $\mathbf{Y}$ & AR \\
\hline & & $\mathbf{N}$ & $\mathbf{N}$ & $\mathbf{Y}$ & AR \\
\hline & & $\mathbf{N}$ & $\mathbf{N}$ & $\mathbf{Y}$ & AR \\
\hline & \multirow{2}{*}{$\begin{array}{l}\text { 1Q, QAP 7-3, Commercial Grade } \\
\text { Item Dedication } \\
\text { - E7, } 3.46 \text { Replacement } \\
\text { Item Evaluation/ } \\
\text { Commercial Grade } \\
\text { Dedication }\end{array}$} & $\mathbf{N}$ & $\mathbf{N}$ & $\mathbf{N}$ & $\mathbf{N}$ \\
\hline & & $\mathbf{N}$ & $\mathbf{N}$ & $\mathbf{N}$ & $\mathbf{N}$ \\
\hline \multirow{2}{*}{$\begin{array}{l}\text { Identification } \\
\text { and Control of } \\
\text { Items }\end{array}$} & \multirow{2}{*}{\begin{tabular}{|l} 
1Q, QAP 8-1, Identification \\
and Control of Items \\
• L1, 8.02 SRNL QA \\
Program \\
Implementation and \\
Clarification
\end{tabular}} & $\mathbf{Y}$ & $\mathbf{N}$ & $\mathbf{Y}$ & $\mathbf{Y}$ \\
\hline & & $\mathbf{Y}$ & $\mathbf{N}$ & $\mathbf{Y}$ & $\mathbf{Y}$ \\
\hline \multirow[t]{5}{*}{$\begin{array}{l}\text { Control of } \\
\text { Processes }\end{array}$} & $\begin{array}{l}\text { 1Q, QAP 9-1, Control of } \\
\text { Processes }\end{array}$ & $\mathbf{N}$ & $\mathbf{N}$ & $\mathbf{N}$ & $\mathbf{N}$ \\
\hline & $\begin{array}{l}\text { 1Q, QAP 9-2, Control of } \\
\text { Nondestructive Examination }\end{array}$ & $\mathbf{N}$ & $\mathbf{N}$ & $\mathbf{N}$ & $\mathbf{N}$ \\
\hline & $\begin{array}{l}\text { 1Q, QAP 9-3, Control of } \\
\text { Welding and Other Joining } \\
\text { Processes }\end{array}$ & $\mathbf{N}$ & $\mathbf{N}$ & $\mathbf{N}$ & $\mathbf{N}$ \\
\hline & \multirow{2}{*}{$\begin{array}{l}\text { 1Q, QAP 9-4, Work Planning } \\
\text { and Control } \\
\qquad \quad \text { 1Y, 8.20, Work } \\
\text { Control Procedure }\end{array}$} & $\mathbf{N}$ & $\mathbf{N}$ & $\mathbf{Y}$ & $\mathbf{N}$ \\
\hline & & $\mathbf{N}$ & $\mathbf{N}$ & $\mathbf{N}$ & $\mathbf{N}$ \\
\hline
\end{tabular}




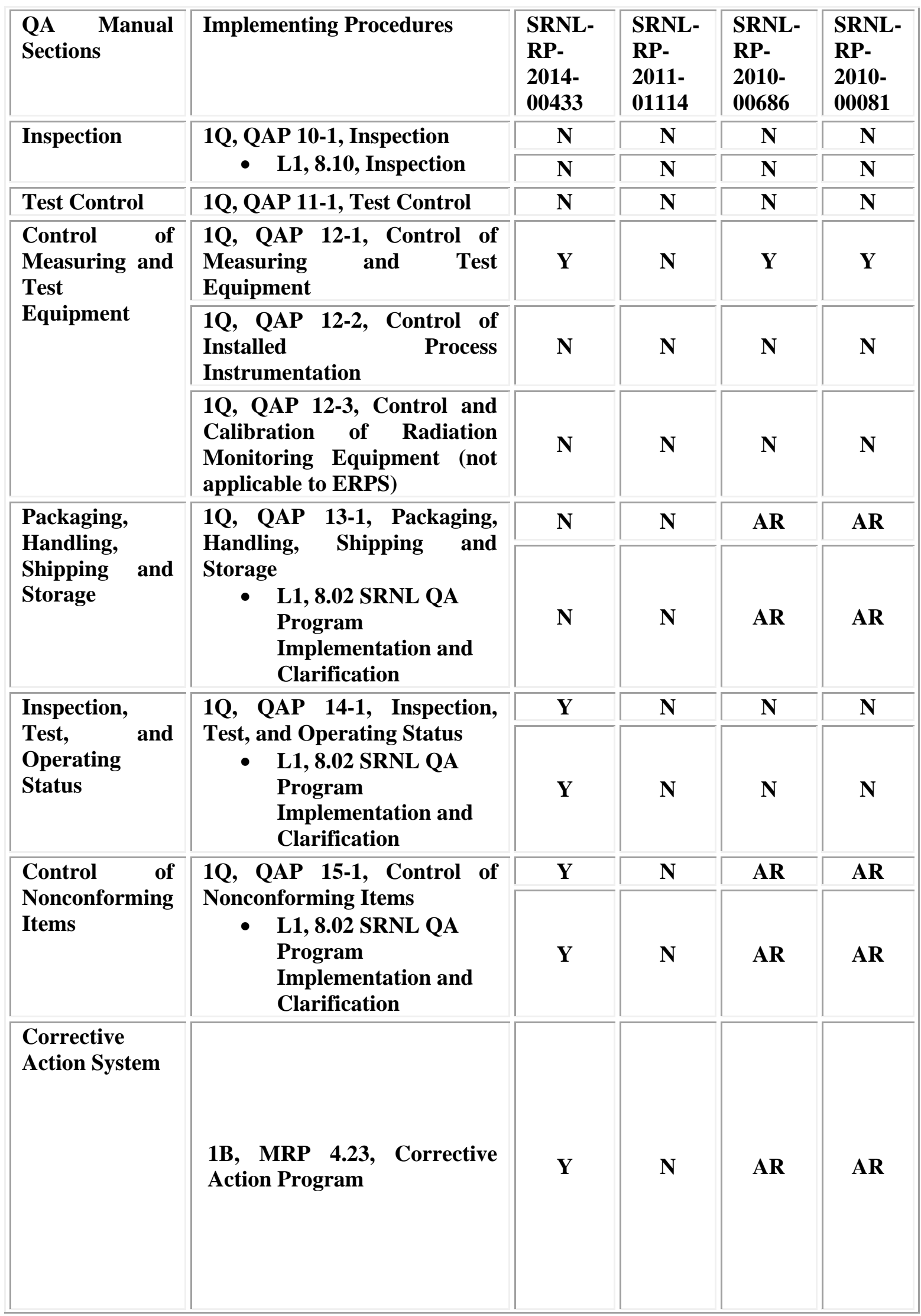




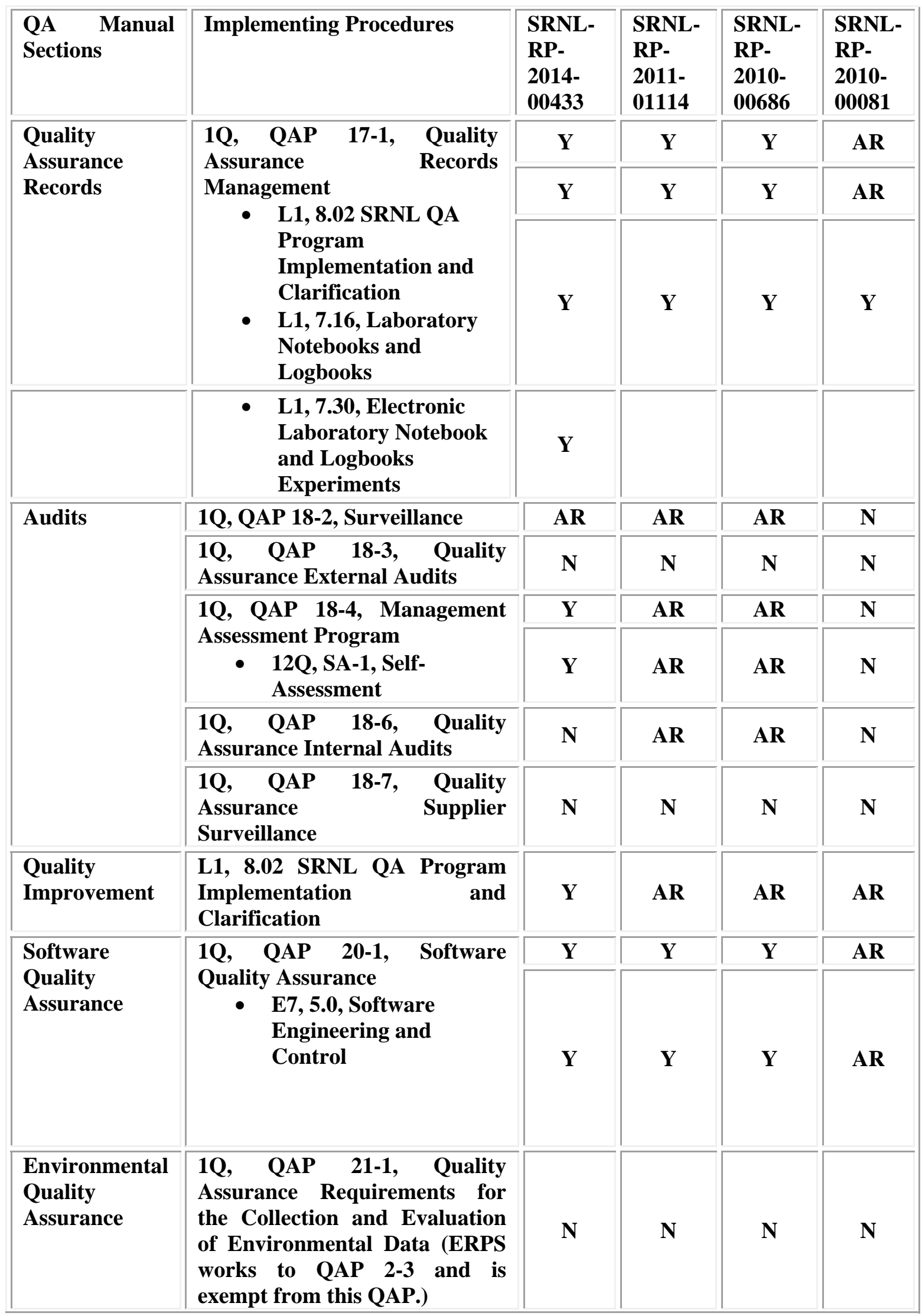




\begin{tabular}{|c|c|c|c|c|c|}
\hline $\begin{array}{l}\text { QA Manual } \\
\text { Sections }\end{array}$ & Implementing Procedures & $\begin{array}{l}\text { SRNL- } \\
\text { RP- } \\
\text { 2014- } \\
00433\end{array}$ & $\begin{array}{l}\text { SRNL- } \\
\text { RP- } \\
\text { 2011- } \\
\text { 01114 }\end{array}$ & $\begin{array}{l}\text { SRNL- } \\
\text { RP- } \\
\text { 2010- } \\
00686\end{array}$ & $\begin{array}{l}\text { SRNL- } \\
\text { RP- } \\
\text { 2010- } \\
00081\end{array}$ \\
\hline $\begin{array}{l}\text { Special } \\
\text { Requirements } \\
\text { (applicable if } \\
\text { RW-0333P QA } \\
\text { program } \\
\text { specified by } \\
\text { customer) }\end{array}$ & $\begin{array}{l}\text { L1, 8.21, Supplemental Quality } \\
\text { Assurance Requirements for } \\
\text { DOE/RW-0333P }\end{array}$ & $\mathbf{N}$ & $\mathbf{N}$ & $\mathbf{N}$ & $\mathbf{N}$ \\
\hline \multicolumn{2}{|c|}{ Is the work Technical Baseline? } & $\mathbf{Y}$ & $\mathbf{Y}$ & $\mathbf{Y}$ & $\mathbf{N}$ \\
\hline $\begin{array}{l}\text { Is the work } \\
\text { Engineering De }\end{array}$ & $\begin{array}{l}\text { R\&D, Routine Service, or } \\
\text { gn? }\end{array}$ & R\&D & R\&D & R\&D & $\mathbf{R} \& \mathbf{D}$ \\
\hline
\end{tabular}

Because of the desire to increase the quality of the data to Safety Significant, design verifications were conducted by performing additional document reviews (according to E7, procedure 2.60, section 5.2) on references $1,2,6,7$, and 13 , The data in those documents was available and rechecked as part of this review. The reviews are documented in Laboratory Notebook SRNL-NB2010-00093. In addition, the M\&TE calibrations were verified as being complete. The M\&TE records for the previous testing described in references $1,2,6,7$, and 13 are stored according to the requirements of $1 \mathrm{Q}$ procedure $12-1$.

\subsection{Discussion}

Based on a review of the pilot-scale SCIX mixing tests and Tank 50 pump operating experience, three standard slurry pumps should be able to suspend solids and MST to effectively sorb strontium and actinides onto the MST.

Using the SCIX data requires an assumption about the impact of cooling coils on slurry pump mixing. The basis for this assumption is described in this report, but the assumption may not be accepted by all reviewers.

Using the Tank 50 operating experience shows three standard slurry pumps should be able to suspend solids if the shear strength of the settled solids is less than $160 \mathrm{~Pa}$. Because Tank 21 does not contain cooling coils, the shear strength could be larger.

Tank 21 contains $\sim 16$ inches of settled sludge. ${ }^{14}$ If the shear strength of this material is less than $160 \mathrm{~Pa}$, the sludge and settled MST should be suspended by the pumps. If the shear strength of the settled solids is greater than $160 \mathrm{~Pa}$, the pumps may not be able to suspend all of the settled solids in the tank, and mounds could form far from the pumps. However, the pumps should be able to keep MST particles ( $<30 \mu \mathrm{m})$ suspended. The MST should be added to the tank with the slurry pumps operating. When the slurry pumps are turned off, the MST and suspended sludge will settle slowly and settle on top of any unsuspended sludge. The MST will settle throughout the tank rather than accumulate at a few locations on the tank bottom. This top layer will have a lower shear strength than the bottom layer or any mounds containing unsuspended sludge. The MST and sludge that was previously suspended will be easier to suspend than any sludge that was not suspended. In addition, the MST does not need to be suspended to enable sorption for subsequent MST strikes. The MST will need to be removed from the tank prior to closure. If the 
sludge is not removed before performing the MST strike, SRR should measure the shear strength of the sludge in Tank 21 prior to performing the first MST strike.

\subsection{Conclusions}

Based on a review of the pilot-scale SCIX mixing tests and Tank 50 pump operating experience, three standard slurry pumps should be able to suspend sludge and MST to effectively sorb strontium and actinides onto the MST.

\subsection{Recommendations}

The author makes the following recommendations:

- Operate the slurry pumps while adding the MST to Tank 21 and performing the MST strike. The slurry pumps should be started and rotating prior to the addition of MST to Tank 21. In addition, the MST should be added as close as possible to one of the mixer pumps. By operating the pumps and adding the MST close to one of the pumps, the MST will be better dispersed throughout the tank, making the sorption process more effective. The sorption time clock should start when the MST addition is complete.

- Remove the sludge from Tank 21 before performing the MST strike. Removing the sludge from Tank 21 prior to the MST strikes reduces uncertainty in the process. Removing the sludge is less important if the added MST is suspended since the strontium and actinide sorption occurs on the freshly added MST. Not removing the sludge prior to the MST strike could make heel removal more difficult at the end of the Large Tank Strike program.

- If the sludge is not removed before performing the MST strike, measure the shear strength of the sludge in Tank 21 prior to performing the first MST strike, and mix the sludge every three months. The three months is based on the pilot-scale SCIX testing and the SCIX Rheology testing. The pilot-scale SCIX testing allowed the solids to settle for four weeks prior to resuspension. The rheology testing allowed samples to settle for up to 13 weeks.

- If routine solids mixing in Tank 21 is not desirable for process reasons, the author recommends that additional rheology testing be conducted with sludge and MST to determine the impact of longer settling times on the slurry rheology. The solids in Tank 21 following the large tank strike will be composed primarily of sludge particles. The SRS Tank Farms have successfully transferred sludge from waste tanks that sat for much longer than three months. 


\subsection{References}

${ }^{1}$ M. R. Poirier, Z. H. Qureshi, M. L. Restivo, T. J. Steeper, and M. R. Williams, "Investigating Suspension of MST Slurries in a Pilot-Scale waste Tank”, SRNL-STI-2010-00793, January 24, 2011

${ }^{2}$ M. R. Poirier, Z. H. Qureshi, M. L. Restivo, T. J. Steeper, M. R. Williams, and D. T. Herman, "PilotScale Testing of the Suspension of MST, CST, and Simulated Sludge in a Sludge Tank", SRNL-STI-201100453, August 2, 2011.

${ }^{3}$ M. R. Poirier and Z. Qureshi, "Scaling Jet Mixing of MST-Containing Solids in the Small Column Ion Exchange Process”, SRNL-STI-2010-00792.

${ }^{4}$ A. V. Staub, "Large Tank Strike Project - Tank 21 Mixing Evaluation”, X-TTR-H-00040,

${ }^{5}$ M. R. Poirier, "Assessment of the Ability of Standard Slurry Pumps to Mix Solids with Liquid in Tank 50H”, SRNL-STI-2011-00688, November 11, 2011.

${ }^{6}$ M. R. Poirier, “Mixing in SRS Closure Business Unit Applications”, WSRC-TR-2004-00153, March 30, 2004.

${ }^{7}$ Leishear, R. A., Fowley, M. D., and Poirier, M. R., “SDI, Blend and Feed Blending Pump Design, Phase 1”, Savannah River National Laboratory, SRNL-STI-2010-00054.

${ }^{8}$ C. Banaszewski, “Tank 50 Solids Mound Volume Calculation”, J-CLC-H-00793, November 1, 2002.

${ }^{9}$ M. R. Poirier, “Tank 50H Solids Rheology”, SRT-LWP-2003-00023, February 13, 2003.

${ }^{10}$ B. V. Churnetski, “Effective Cleaning Radius Studies”, DPST-81-282, February 19, 1981.

${ }^{11}$ B. V. Churnetski, "Prediction of Centrifugal Pump Cleaning Ability in Waste Sludge", Nuclear and Chemical Waste Management, Vol. 3, Issue 4, pp. 199-203, 1982.

${ }^{12}$ M. R. Powell, Y. Onishi, and R. Shekarriz, "Research on Jet Mixing of Settled Sludges in Nuclear Waste Tanks at Hanford and Other DOE Sites: A Historical Perspective”, PNNL-11686, September 1997.

${ }^{13}$ M. R. Poirier, C. E. Ferguson, D. C. Koopman, and T. B. Edwards, "Rheology of Settled Solids in Small Column Ion Exchange Process”, SRNL-STI-2011-00311, June 20, 2011.

${ }^{14}$ T. A. Le, “3/31/2014 - March 2014 Curie and Volume Inventory Report”, SRR-LWP-2014-00014, Rev. 0, April 2014. 